\title{
ASSESSMENT OF ENTREPRENEURIAL OPPORTUNITIES OF MAMANWA TRIBE IN BASEY, SAMAR: A CASE STUDY
}

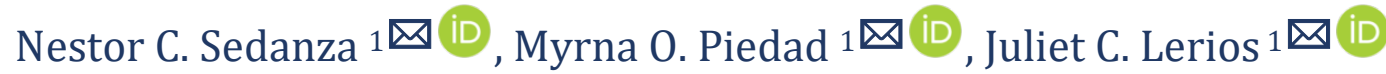 \\ ${ }^{1}$ Leyte Normal University, Tacloban City, Philippines
}

DOI: https://doi.org/10.29121/granthaalayah.v9.i1.2021.3097

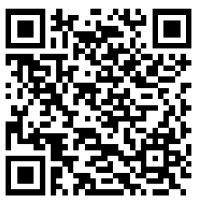

Article Type: Research Article

Article Citation: Nestor C. Sedanza, Myrna O. Piedad, and Juliet C. Lerios. (2021). ASSESSMENT OF

ENTREPRENEURIAL OPPORTUNITIES OF MAMANWA TRIBE IN BASEY, SAMAR: A CASE STUDY. International Journal of Research -GRANTHAALAYAH, 9(1), 183-188.

https://doi.org/10.29121/granthaa layah.v9.i1.2021.3097

Received Date: 01 January 2021

Accepted Date: 31 January 2021

Keywords:

Mamanwa

Indigenous Peoples

Entrepreneurial Initiatives

Sources of Income

Case Study

\section{ABSTRACT}

One of the priorities of Education for Sustainable Development (ESD) 2030 is poverty eradication with emphasis on the marginalized and indigenous peoples (UNESCO). The migrant Mamanwas in Basey, Samar composed of 24 families rely on the subsistence economy which is handto-mouth existence. The theory of personal resourcefulness emphasizes in one's own capability for initiating actions towards creation and growth of enterprise (Kulkarni, 2016). This qualitative study sought to examine the entrepreneurial initiatives of Mamanwas that helped them sustain their existence. It employed evaluative qualitative research method - single case study, the Mamanwa tribe. The data were collected through observations, in-depth interviews, and focus group discussion. The data were analyzed through two cycles of coding and categories and themes were developed. The findings revealed that Mamanwas' sources of income were farming, gathering of rattan and abaca, grass cutting, mat weaving, handicrafts, and making of souvenir items. However, they needed technical assistance in the preparation of souvenir items and checking whether it pass quality standards, they also lack materials and tools and a strategy in marketing their products, they want training on food preparation and cooperative education. This study recommended for an extension project proposal on training and technology assistance for entrepreneurs.

\section{INTRODUCTION}

The Mamanwa (Conking, Mamaw, Amamanusa, Manmanua, Mamaua) is one of the three groups of ethnic tribes that occupy a very distinct position in Philippine populations. Heretofore, the Mamanwa has been classified as a Negrito subgroup, but physical anthropological data indicate otherwise. The Mamanwa form a distinct branch from the rest of the Philippine populations which include the various groups of the Negrito, and the Austronesianspeaking people which now comprise the modern populations. The mamanwa appear to be an older branch of population appearances in the Philippines affecting to some extent the Negrito of Northeastern Luzon. Like all the Negrito groups in the country, the Mamanwa speak a language that is basically, that of the dominant group about them. (NCCA, 2015).

The Mamanwas are short, small-framed people. They have dark skin, kinky hair and shy personalities. Their names are derived from nature - mountains, bodies of water, trees, stones, and wildlife. Basically, nomadic, the older men of the tribe still roam the forests of Surigao del Norte to hunt for food, returning only to their territories to deliver their catch, which are shared by everyone. In recent times, the younger ones begun to look for work at mining

(C) 2021 The Author(s). This is an open access article distributed under the terms of the Creative Commons Attribution License, which permits unrestricted use, distribution, and reproduction in any medium, provided the original author and source are credited. 
and logging companies, to earn money to support the needs of their young families (USAA 2003). This study assessed their entrepreneurial activities for both men and women to earn money for their families.

Maceda (1967) classified Mamanwas into three groups economically: food collectors, transitional groups, and semi-sedentary groups. A few of them own lands now and have become both famers and food collectors. The more acculturated Mamanwas also have domesticated pigs' chickens for food and sacrifices. Camote, a tropical sweet potato, is their basic crop. In the steep mountains Mamanwas practice slash and burn agriculture. Further they hunt and trap wild pigs, deer, and wild chickens. A limited of corn, sugarcane, tobacco, squash, and bananas are grown. It is not uncommon for one family to plant and others to live off of them. (Miller et.al.,1976).

The Mamanwas are more scattered and nomadic compared to other tribal groups. However, most Mamanwa groups are concentrated in Eastern Visayas and Northeastern Mindanao (Surigao del Norte and Agusan del Norte). Different sources placed the present Manmanwa population around 2,000 to 8,000. (Diaz, 2015). Some of these group migrated to Samar and Southern Leyte. A group of Mamanwas composed of 24 families migrated to Sitio Wispal, Brgy. Guirang, Basey, Samar. They came from Dolores, Eastern Samar. This Mamanwa tribe in Basey was the subject of this study.

The preliminary survey conducted by Espada in 2017 pointed to the Mamanwas with 24 families in Basey, Samar as indigent group who are in dire need of help in all aspects. Some of her findings were the following: 1) the migrant Mamanwas are female dominated, aged 31 to 40 years old, mostly parents; 2) only half of them reached elementary; the other half are illiterate who expressed their desire to learn to read; 3) As farmers, they sell raw abaca and rattan at a very low price; 4) they live in wooden bamboo houses with no electricity and own water supply; 5) can hardly sustain basic needs; and 6) they possess negative self-concept and low-esteem. The findings clearly imply that they struggle for survival.

In another development, the Department of Tourism (DOT) have included the Mamanwa tribe in the tourism loop of Samar since their place is a jump-off point to the Sohoton Cave Bridge Park, a popular tourist destination in Eastern Visayas. The Provincial Government of Samar and DOT donated traditional musical instruments and clothes for Mamanwa tribesmen to preserve their traditions and culture. The tribesmen can be an attraction to locals and tourists by their culture, traditions and history of the tribe for better appreciation of their presence. The Mamanwas makes souvenir items for tourists going to the cave. They sell necklaces made of seeds, pen made of bamboo, garland made of tikog leaves and other products. The income they receive from making and selling souvenir items help support the daily needs of their families.

It is in this context that the study was undertaken. The findings will greatly help in generating ideas on how to help them sustain their entrepreneurial activities as an alternative source of livelihood for their families.

\section{FRAMEWORK OF THE STUDY}

One of the priorities of Education for Sustainable Development (ESD) 2030 is poverty eradication with emphasis on the marginalized and indigenous peoples (UNESCO). Research findings show that education plays a vital role in the eradication of this condition.

The new thrust of education for sustainable development emphasizes improving access and retention in quality basic education, reorienting existing educational programs to address sustainability, increasing public understanding and awareness of sustainability and providing training to all sectors of the workforce. This sustainability should be holistic that it should include not only knowledge acquisition but also the socio-economic, cultural. Skills acquisition and environment awareness in a given society or culture.

The many shifts of processes and activities in the world displaced an identified group of minorities- the indigenous peoples. They suffer the consequences of economic advancement such as mining, large scale farming, cattle raising, industrial growth and even land grabbing, ejecting consequences like hunger, poor health conditions, displacement, discrimination, loss of culture, cultural erosion, conflicts, abuse, sickness and inequality among others. Teachers can do so much to help educate the marginalized indigenous youth to get them out of this extreme condition.

But some observations suggest that the present educational system is geared towards the western model, making the marginalized become more alienated with knowledge that is offered. Worst, the learners who completely embrace this type of education cannot find the relevance in their present life or those who are able to advance their education to a higher level totally forget and discriminate their own culture and ways of learning and doing things. 
The marginalized and indigenous need is education that will lead them to new paths of learning to do things applicable in their own contexts, to make them sustainable through lifelong learning without eliminating the roots of their knowledge and culture.

As part of the joint research project between Leyte Normal University (LNU) and United Nations, Scientific, Educational and Cultural Organization (UNESCO) entitled: Documenting the Life and Culture of the Indigenous Peoples in the Philippines: A Case Study of the Mamanwa Tribe in Basey, Samar for FY 2017-2020 which is aimed to eradicate poverty of the marginalized and indigenous groups by "reorienting the teacher education program", this study's contribution is on sourcing baseline data on demographics: livelihood /social security.

In addition, the theory of personal resourcefulness (Kulkarni, 2016) emphasizes in one's own capability for initiating actions towards creation and growth of enterprise. One half of the Mamanwas in Basey had only reached elementary education, the other half are illiterate who expressed their desire to learn to read (Espada, 2017). So, it is interesting to know how the Mamanwas survived and they can hardly sustain their basic needs as reported by Espada (2017). Therefore, this study looked into the entrepreneurial initiatives of Mamanwas considering them educational attainment and living condition. The findings of this study will be the basis in proposing a researchbased extension project to help equip the Mamanwa tribe to enhance them entrepreneurial skills and to sustain their livelihood and improve their quality of life.

\section{OBJECTIVE OF THE STUDY}

This study sought to examine the entrepreneurial opportunities of Mamanwa tribe in Basey, Samar. Specifically, it sought to answer the following questions:

1) What are the current sources of income of the Mamanwas?

2) What are the products they sell?

3) What are the needed raw materials used in producing the products?

4) How they produce the products?

5) What is the most in demand product they produce and sell?

6) What kind of assistance they need in producing the products?

\section{METHODS}

\section{Research Design}

The study utilized an evaluative case study design-single case (Merriam 1998). It employed guide questions indepth interview and focus group discussion in obtaining the data from the respondents. Likewise, observations were conducted when the researchers visited the respondents in their houses.

\section{Sampling}

This study used the purposive sampling since the investigator will focus on a particular group of IPs only. The inclusion/exclusion criteria on the participants are as follows: 1) Member/s of the tribe who are engaged in livelihood activities; 2) Must be able to express one's self using a language that is understandable both to the informant and the researcher/investigator.

\section{Participants}

The participants/informants in the study were the Mamanwa tribe members in Basey, Samar.

\section{Data Gathering and Analysis}

In gathering data for this study, a permit from the gatekeepers - the tribe chieftain, the pastor, the Barangay Captain., the Municipal Mayor was sought. Then, a scheduled visit for the focus group interview was set. During the interview and focus group discussion, informants who were available at the time of visit were gathered in one house and were asked questions following the instrument guide. Likewise, observations to respondents during house visits were conducted. The data gathered was analyzed through two cycles of coding, categories and themes were developed (Wa-Mbaleka and Gladstone, 2018). 


\section{Ethical Considerations}

An informed consent was sought from the participants as well as permission from the gatekeepers were sought. The participants were assured of the confidentiality of their answers to questions. Respect to the participants was observed throughout the study. Names of the participants were not used, instead codes were used in reporting the data.

\section{Findings}

The findings are presented below based on the research questions and themes of the study:

\section{Sources of income}

The main source of income of the Mamanwas is farming and other related agricultural jobs, handicraft and mat weaving, abaca and rattan gathering, and souvenir making like necklace, bracelet, key chain and refrigerator magnet. Likewise, Espada, 2017 reported that Mamanwas harvested abaca and rattan and sell it in the town at a very low price. Sometimes they use rattan to make baskets and sell it also at a low price. NCCA, 2015 reported the lifeway of the Mamanwa is founded on slash-and-burn cultivation on small patches and minimal wet rice agriculture. Food gathering is heavily relied upon.

\section{Products for sell}

The Mamanwas are engaged in handicrafts and souvenir making thus they are selling products to the public such as bracelet ring, necklace, basket, key chain, erring, refrigerator magnet seed, "banig" made of tikog and "duyan" made of rattan. Somkumar, 2007 hammocks, and other household containers. In addition, Espada, 2017 revealed that a 35-year-old mother of five sells souvenir items like pen abd necklace at the tourism office in Basey. She sells the necklace for P50 while the pen is worth P20. On the other hand, Miller et. al, 1976 reported that in the past Mamanwas practiced silent bartering. Their honey or wild pig were exchanged with bananas or other items. They also have a practice in large scale trade of rattan, abaca, and woven sleeping mats.

\section{Raw materials needed}

In the production of souvenir items and handicrafts, they needed the following raw materials: nito (black and brown) used in preparing bracelet ring, necklace and key chain; "uway" or rattan used in preparing basket, "duyan", "kaing", hammocks, etc.; abaca used in making ropes, bags and decors, "kawayan" or bamboo used in preparing pens, house materials and souvenirs; and "agsam" used in preparing erring, bracelet, and placemat; tikog leaves used in making garland and mat. Espada, 2017 revealed that Mamanwas sells necklaces made out of seeds called kabugkabug from the salugay vine that thrives in the thick forest, about 25 kilometers away from their community.

\section{How products are made?}

The souvenir items and handicraft products are made manually, a traditional method using knife, wires and other tools. They started using the traditional method since when they learn how to make the products.

\section{Most in demand product}

Among the handicrafts and souvenir items that Mamanwas were producing, the most in demand product is the refrigerator magnet seed. All of the participants answered the same product which is easily sold out or bought by the buyers.

\section{Assistance needed in making and selling the products}

In spite of their skill in handicrafts and souvenir making and the training they've got from Department of Trade and Industry (Espada, 2017), the Mamanwas are still in need of assistance in making and selling their products. One of the commenst of the participants was "I hope to have a regular buyer and to improve the quality of my products and for me to have a better income to support the daily needs of my family". So, the Mamanwas want to have materials like magnet, beads, string, tools, machines and designs. They needed technical assistance on product quality assessment. They also lack marketing skills including cooperative education. This finding corroborated to Espada,2017 in her findings that Mamanwas needed assistance like skills training but also equipment, materials, marketing and promotion of their products. 


\section{SUMMARY, CONCLUSION AND RECOMMENDATION}

The entrepreneurial activities of Mamanwa tribe in Basey, Samar is quite impressive despite of their lack of education and living condition. Their traits, resilience and positive attitude towards life significantly contribute to a brighter future ahead.

The theory of personal resourcefulness was proven in this study that Mamanwas are capable on their own initiative to initiate in improving their quality of life.

The main source of income of the Mamanwas is subsistence farming. However, they are also engaged in making and selling products to augment their income for their daily sustenance. The products that they produced are handicrafts and souvenir items which they made manually or traditionally. They are using raw materials like abaca, rattan, seeds etc. in making the souvenir and other household products. The most in demand product is refrigerator magnet seed. However, they lack materials, tools, designs and other assistance like training in marketing their products as well as food preparation and cooperative education.

Therefore, based on the findings of this study, an extension project proposal on technology assistance and training for entrepreneurs will be proposed and implemented to enhance the entrepreneurial skills of Mamanwas.

Also, a follow-up study be conducted one year after the implementation of the project.

\section{SOURCES OF FUNDING}

This research received no specific grant from any funding agency in the public, commercial, or not-for-profit sectors.

\section{CONFLICT OF INTEREST}

The author have declared that no competing interests exist.

\section{ACKNOWLEDGMENT}

None.

\section{REFERENCES}

[1] Asia Pacific Association for Basic and Adult Education (APABAE

[2] Ekoto, Christian E. (2017). Training Handout on Qualitative Case Study Design: A Compilation. Asian Qualitative Research Association (AQRA), Silang, Cavite, Philippines

[3] Espada, Janet Presnilla (2017). An Ethnography - The Mamanwa Diaspora: Exploring Challenges Underneath the Search for Lost Identity. Unpublished research: Leyte Normal University, Tacloban City

[4] Espada, Janet Presnilla. (2017). Documenting the Life and Culture of the Indigenous Peoples in the Philippines: A Case of Mamanwa Tribe in Basey, Samar. A Research and Extension Project of Leyte Normal University.

[5] German, M.A. (2010). The Mountain People of the Philippines: A Review of Selected Literature

[6] Hammarstrom, Harald; Forkel, Robert; Haspelmath, Martin, eds. (2017) "Mamanwa". Glottolog 3.0. Jena, Germany: Max Planck Institute for the Science of Human History

[7] Masendo, A. (2015) The Manobo Tribe Then and Now, 227: An Ethnography.International Journal of Scientific and Engineering Research,Volume 6, Issue 4, 227 ISSN 2229-5518 IJSER

[8] Meriam, S.B. (1998). Case study research in education: A Qualitative approach. San Francisco, CA: Jossey-Bass.

[9] Miller, et.al. (1976). Mamanwa Grammar. Huntington Beach, CA: Summer Institute of Linguistics.

[10] National Commision for Culture and the Arts (NCCA), 2015. Mamanwa.

[11] Asia Pacific Association for Basic and Adult Education (ASPBAE) (2017) Policy Brief on Indigenous People's Education in the Philippines. Colaba-Mumbai, India.

[12] Resture, Jane (2011). The Mamanwa People of the Philippines. 
[13] Safari, Wa-Mbaleka \& Ranjit Kinston Gladstone (2018). Qualitative research for senior high chool. Oiokos Biblios Publishing House, Silang, Cavite, Philippines

[14] Somkumar, A. (2007) Mamanwas and Their Fight Against Poverty. South Asian Outlook, Global Media.

[15] oriano, et.al. (2007). Civil Society Network for Education Reforms, Indigenous People's Education in the Philippines.

[16] UNDP, 2010. Fast Facts: Indigenous People in the Philippines.

[17] USAA Scholarship Program (2003). About the Mamanwa. 